\title{
The My Student Leader App: How mobile technology enhances campus service leadership initiatives
}

\author{
Lisa A. Mainiero, Ph.D \\ Professor of Management \& Leadership \\ Dolan School of Business \\ Fairfield University \\ David M. Mangini, M.B.A., M.S. \\ Global Strategist \\ Mangini Strategic Advisors, L.L.C
}

\begin{abstract}
This article showcases how mobile app technology can enhance leadership education through a new mobile app called My Student Leader. My Student Leader represents a novel approach to leadership education so that students may use smartphone technology to enhance student leadership development on campus. The app facilitates the creation of Leader Plans associated with service learning activities and campus events which then can be emailed to team members, faculty and staff. There also is a section for students to write a Leadership Legacy reflection. This application brief addresses the stages of development of the app and the outcomes associated with mobile technology use for leadership education.
\end{abstract}

\section{Issue Statement}

Campus leadership activities offer many opportunities for students to connect classroom learning to leadership practices. Ideally, campus leadership should take place simultaneously with classroom learning so that practical insights can be applied to real-time leadership initiatives. However, often there is a dis-connect between what students learn in theory and cocurricular activities involving peer leadership. The purpose of this article is to demonstrate a new tool in leadership education - the My Student Leader app. The app demonstrates how mobile smartphone technology can be used to help students: 1) plan campus leadership activities in advance, 2) utilize leader tips to craft a unique Leader Plan, and 3) develop a Leadership Legacy reflection. We share the stages of development of the My Student Leader app, identify outcomes from use of mobile technology in enhancing leader education, and suggest recommendations for future leadership app developers.

\section{Review of Related Scholarship}

On campus, students often lead co-curricular activities with shared leadership responsibilities and mutual objectives. There are captains of sports clubs, dorm resident advisors, intramural club presidents, fundraising for charitable foundations, mission-directed student service learning opportunities, social justice initiatives, business case and group classroom projects, intramural activities, and official student government roles, all of which require 
leadership skills. To be successful, students must develop shared, peer-driven leadership skills (Friedel, Kirland, \& Grimes, 2016). Pearce and Sims (2000) define shared leadership as a process of shared influence between and among individuals that can emerge in a group context. As shared leadership takes hold, a group psyche of commitment and contribution emerges (Fletcher \& Kaufer, 2003; Pearce \& Conger, 2002; O’Toole, Galbraith, \& Lawler, 2003).

Learning through peers may have a significant impact on student leadership development and may create powerful self-insights (Kuh, Kinzie, Schuh \& Whitt, 2005). Action-driven learning experiences help students apply what they have learned to real life situations alongside peers so that leadership theory becomes more meaningful (Hastings, Wall \& Montoya, 2018). Motivating peers may become a vital skill in the non-hierarchical, flatter, twenty-first century landscape (Friedel, Kirland, \& Grimes, 2017). Ideally, a shared, peer-driven leadership model should reflect non-hierarchical, team oriented, and community values based on trust and shared understanding for the greater good (Outcalt, Faris, \& McMahon, 2001).

Service Learning and Leadership Pedagogy. Service learning initiatives, derived originally from Greenleaf (1977) and Kolb (1984) can serve as an incubator for learning about peer-driven, shared leadership. Linking specific service learning and other co-curricular experiences to leadership theory can enhance leadership practice (Kalinovich \& Marrone, 2017; McKim \& Velez, 2017). For example, students may participate in community engagement initiatives to support the homeless, work on fundraising initiatives for cancer foundations, or create $5 \mathrm{~K}$ runs to support a noble cause, and then reflect on their experiences for a classroom assignment. Service learning integrates active experiential learning with community-based scholarship, intellectual rigor, and holistic personal growth (van Dierendock, 2011). Service learning experiences can increase pro-social motivation (Vega, 2007) and improve student selfefficacy and self-esteem (Eyler, Giles, Stentson \& Gray, 2001; Kenworthy \& Fornaicari, 2010; Yorio \& Ye, 2012).

However, some service learning experiences fall short of the ideal in which students reflect on their experiences and connect theory to their activities (Mitchell, 2008). Butin (2006) critiqued service learning experiences on campus and found a significant disconnect between the activity and what students actually learn. Service learning in leadership education must connect the dots between theory and practice so that students develop deeper meaning (Stover \& Seemiller, 2017). For example, Bauermeister, Greer, Kalinovich, Marrone, Pahl, Rocholz, \& Wilson (2015) offer a template for integrating a challenging class project with community initiatives to develop self-awareness of leadership style, interpersonal skills in managing relationships, designing a team structure, and executing a project. Werner, Hellstrom, Chung, Kessenich, Taylor, \& Capeder (2016) also suggest using an evidence-based leadership pedagogy to bridge the gap between leadership theory and student practice.

Connecting Theory with Mobile Technology. Mobile technologies, such as online learning platforms and especially smartphone technology, can serve as a mechanism to record leadership insights, create reflections on leader practices, and triangulate peer-driven cocurricular leadership experiences in a meaningful way. Millennials are digital natives who live in a world of real-time information and connect hourly with rapid mobile capabilities (DeBlois \& Oblinger, 2007). Universities offer online courses to expand their reach with robust learning 
management systems that Millennials and Generation $\mathrm{Z}$ members appreciate (Whitaker, New \& Ireland, 2016). Many professors, capitalizing on the promise of online and mobile technology, add Google Docs to classes and encourage interaction via Facebook, Twitter, or Snapchat on projects (Lantz-Andersson, Vigmo \& Bowen, 2013; Odom, Jarvis, Sandlin \&Peek, 2013). Professors may benefit from mobile technology adaptation in service of leadership education (Guthrie, 2009).

More recently, the technology available on smartphones and mobile applications has blossomed, creating new opportunities for leadership education. Some mobile "knowledge apps" have a pedagogical component (e.g. math fluency apps for children, language-learning apps, or brain-training apps for seniors). Montiel, Delgado-Cerballos, and Ortiz-de-Mondojana (2017) for example, recently published a review of a knowledge app called, "Good Guide" to determine its application regarding the health, environment, and social impacts of food to classes on sustainability. To bridge the gap between live service learning opportunities, campus cocurricular initiatives and leadership pedagogy, it is time to consider the use of mobile technology for students leading peers.

\section{Development of the Application: The My Student Leader App}

The My Student Leader app is a tool to help students develop customized Leader Plan templates for a variety of live campus student leadership activities involving fundraising, running events, and service learning objectives. Grounded in leadership research, the app guides students through a menu of peer oriented, collaborative leadership tips. Students can create customized templates for Residence Advisors, Athletic Captains, Event Planners, Fundraising Events, Business Case Groups, Campus Tour Guides, Club Activities, Corporate Internships, Group Projects, Mentors, House Presidents, Retreat Leaders, Senior Week Chairs, Service for Justice Coordinators, Student Government Leaders and Student Orientation Leader responsibilities, among others. Specific Leader Plans can be formulated based on the leadership tips for each Leader Plan template. In addition, there is a notepad that can be tied to the phone's calendar to help students remember what they must do to accomplish their leadership activities. The app also includes a reflection section where students write notes about their Leadership Legacy to spur improvement in the future.

Stages of Development of the My Student Leader App. The app was developed at a small Jesuit university in the Northeast of 4,500 students with an active business school that competitively accepts around 1000 students of the total population per year. Students registered for an undergraduate leadership course (Mg 240, Leading and Managing People) between Spring 2013 and Spring 2017. Students were juniors and seniors, ages $20-22$, who were interested in the subject of leadership and were Management majors or minors. A core group of 42 students participated in the direct development of the app; over 255 students prepared Leader Plans over ten semesters. All students volunteered to participate in app development as they were interested in how app technology could be applied to leadership on campus.

As the professor, I became the primary researcher of this initiative while on sabbatical. I finalized the content for the app, so I am referred to within as "Content Creator". However, as I am not technically driven, my co-author became the "Technical Creator" who supervised the 
app's coding and software development. As Content Creator, I developed a series of leader tips to establish content for the app. I also collected commentary from students each semester to discern how the app enhanced leadership learning. The Technical Creator encoded the app's functionality and worked with software developers to bring the app to fruition.

I. Initial Steps - Fall 2012. To develop the app, a series of iterative steps were taken between myself, as the Content Creator, and the Technical Creator, alongside student volunteers. I gave a list of initial leadership tips to a focus group of eight students in $\mathrm{Mg} 240$ who were: 1) management majors interested in leadership, and 2) serving in major leadership roles on campus. Each student vetted the initial set of leadership tips. The consensus from the initial focus group was informative. The students stated my content was "too wordy", the list of themes was too much, and that Millennials want "quick sound-bite phrases that provide practical immediate information they could actually use". Students individually edited the leader tips to make them more succinct.

II. Pre-Coding Content - Spring 2013. Returning from sabbatical armed with student feedback, I formulated small teams of student volunteers who were interested in volunteering for app development. This new student focus group culled down the numerous leadership tips to a more manageable list and size. I consulted with two Student Affairs professionals on campus to discern key leadership themes appropriate for campus leadership. Six themes were generated: Creating Inclusion, Handling Logistics and Planning Events, Maintaining Engagement, Fostering Team Collaboration, Mentoring and Coaching Performance, and Managing Stress and Time Management. These themes were chosen as they resonated with student affairs professionals as well as students. Shorter, more practical leader tips were chosen associated with each theme that resonated with theory. The full set of leader tips is available on the app (see Figure 1 screenshots for a sample.)

III. Developing Leader Plans - Fall 2013. The next semester, a third focus group was created of twelve new volunteers interested in the app development. These students represented many different campus leadership roles, and were actively involved in fundraising events, social justice awareness events, athletic teams, resident hall advising, freshmen orientation, and other roles. This third group identified leader tips associated with general templates for leadership that would resonate with key campus leadership roles. Each student had the ability to customize a template to suit their own leadership objectives. Sample template Leader Plans were generated by students in those roles and included templates with suggested leader tips for Athletic Captains, Resident Hall Advisors, Student Club President, Fundraising Leaders, Business Case Group Leaders, New Student Orientation Leader, Campus Tour Guides, and Student Government Leader. These Leader Plans became the basis for the app's functionality.

IV. Technical Development - Summer and Fall 2013. Once the leader tips, plans, and functionality of the app were established, the Technical Creator contracted 
with a commercial software developer to produce and execute the app according to specifications. This process involved a series of meetings between the commercial software developer, the primary coder, and the app's Technical Creator. Screenshots of app pages and functionality were evaluated by the Technical Creator of the app, along with myself as the Content Creator of the app. To locate the app within the Apple App Store, an LLC was established, and appropriate legal forms and tax forms filed. A technology development grant and a research grant were provided to offset development costs. The process of app design and technical evolution took six months.

V. Rollout - Fall 2014. Once Version 1.0 of the My Student Leader app went live in February 2014 in the Apple App Store, we asked current students in Mg 240 to complete optional Leader Plans and provide feedback concerning those plans as a pilot test of the app. One requirement of the $\mathrm{Mg} 240$ class is a demonstration of leadership potential. The Leader Plan served that requirement in the grading system, though it remained optional, for extra credit. Table 1 offers a sample leader plan for a New Student Orientation Leader role:

Table 1

New Student Leader Plan (Sample)

\begin{tabular}{ll}
\hline Leader Tip & Description of Leader Tip \\
\hline Leader Tip \#1: & $\begin{array}{l}\text { Communication is central to leadership. Maintain a two-way flow of } \\
\text { communication between yourself and each member of your team. Check } \\
\text { with each participant and ask, "How can I help? What is going well? What } \\
\text { isn't? How can we do this better?" }\end{array}$ \\
\hline Leader Tip \#2: & $\begin{array}{l}\text { Expect conflict to emerge as groups evolve. This is often called the } \\
\text { "storming" stage because participants may have different ideas for method or } \\
\text { purpose of accomplishment. Your job is to serve as a facilitator of the } \\
\text { different points of view, and to generate a consensual solution to the problem } \\
\text { at hand. }\end{array}$ \\
\hline Leader Tip \#3: & $\begin{array}{l}\text { Remember to lead between the meetings. Good leaders also mentor and } \\
\text { coach from the sidelines. In between meetings, catch up with your people } \\
\text { and ask them how things are going, and what obstacles are in the way of } \\
\text { meeting their deadlines. Leading between the meetings is essential for team } \\
\text { success and stress management. }\end{array}$ \\
\hline Leader Tip \#4: & $\begin{array}{l}\text { Provide structure and clarity of direction. Keep everyone focused on the } \\
\text { ultimate goal. If consensus is reached, you will enjoy a successful team } \\
\text { experience. If some feel they have "lost", they may be less willing to } \\
\text { participate later on. }\end{array}$ \\
\hline Leader Tip \#5: & $\begin{array}{l}\text { When personal conflicts arise, don't allow a conflict to sour the group } \\
\text { experience. Manage conflict openly when it arises. Articulate the problem } \\
\text { and ask for ideas to solve the problem at hand. }\end{array}$ \\
\hline $\begin{array}{l}\text { Serve as a facilitator rather than a manager. Rather than telling the student } \\
\text { what to do, ask for ideas. Facilitate learning by asking the student, "What do }\end{array}$ \\
\hline
\end{tabular}




\begin{tabular}{ll}
\hline & $\begin{array}{l}\text { you think went wrong here?" or "What went well?" "What would you do } \\
\text { differently next time?" }\end{array}$ \\
\hline Leader Tip \#7: & $\begin{array}{l}\text { Make disagreements principle-based rather than personality-driven. If it is } \\
\text { necessary to disagree with or challenge the comments of others, focus on } \\
\text { how you can both "win". Identify commonly held values that can be used to } \\
\text { orchestrate a common solution. }\end{array}$ \\
\hline Leader Tip \#8: & $\begin{array}{l}\text { Divide up large projects. Feeling a task is too large leads to a feeling of } \\
\text { being stressed and overloaded and can foster procrastination. Instead, create } \\
\text { smaller "chunks" that are manageable, and accomplish them one at a time. }\end{array}$ \\
\hline Leader Tip \#9: & $\begin{array}{l}\text { Manage "absentees" who do not attend meetings through direct } \\
\text { conversation. Ask whether or not they remain committed to the task. Insist if } \\
\text { they no longer can participate that they find someone else who can fulfill } \\
\text { their role. }\end{array}$ \\
\hline Leader Tip \#10: & $\begin{array}{l}\text { Demonstrate supportive listening. Listen first, rather than tell people what to } \\
\text { do. Resist the temptation to be directive. Instead, listen upfront. Then use } \\
\text { dialogue to craft an idea or plan. }\end{array}$ \\
\hline Leader Tip \#11: & $\begin{array}{l}\text { Communicate, communicate again, and over-communicate! Everyone should } \\
\text { be kept aware of decisions that are made and events being planned so they } \\
\text { can volunteer their time as needed. Use social media to keep everyone } \\
\text { updated if they cannot make a meeting. }\end{array}$ \\
\hline Creade SMART goals (Specific, Measurable, Aligned, Realistic, and \\
Timebound) to manage team accomplishments. While doing so, identify \\
reasonable deadlines to go along with the goals.
\end{tabular}

VI. Feedback on Version 1.0 - Spring and Fall, 2015. In 2015, a new focus group of fifteen students indicated there was a need for a way for students to create a list of duties, responsibilities, and tasks associated with each leader assignment. For Version 2.0, students wished to connect notes to their phone's calendar functionality to set off reminders each week about leader responsibilities. So, for example, if a student leader wanted to remember to "Order pizza for next week's meeting", that task could be listed under Notes to Self, and a reminder would come up on their smartphones when set by the student as a reminder before the meeting time.

VII. Final Steps for Version 2.0 - Spring and Fall 2016. The app required technical redevelopment at this time, so we redesigned aspects of the app based on student feedback. Version 2.0 included Notes to Self and a reflection on one's personal Leadership Legacy. Users were asked, "What are the top ten leadership lessons you have learned from leading this student activity?" and "How can you improve your leadership legacy as you move into new leadership roles?" Finally, it was suggested that Leader Plans be shared via email so that the next campus leader could view the previous Leader Plan and customize it for them for the next year as required. Email functionality was then added to the app.

VIII. Version 2.0 Rollout- Spring 2017 and Fall 2017. Version 2.0 was made available in the App Store with a slightly changed title of My Student Leader in 
January 2017 with full email functionality. In addition, Version 2.0 allows for social media to be incorporated into the app; photos from $\mathrm{Mg} 240$ projects attached to the app's Facebook, Twitter, and Instagram accounts could then be posted on social media. A group of eight additional students posted photos of active student learning projects on social media and added leadership commentary to encourage widespread adoption of the app across campus. Screenshots of the app in Version 2.0 are pictured in Figure 1.

Currently, the app is undergoing revision to move to a website format. In the future, the mobile app will be accessed through studentdigitalleadership.com for ease of use. 


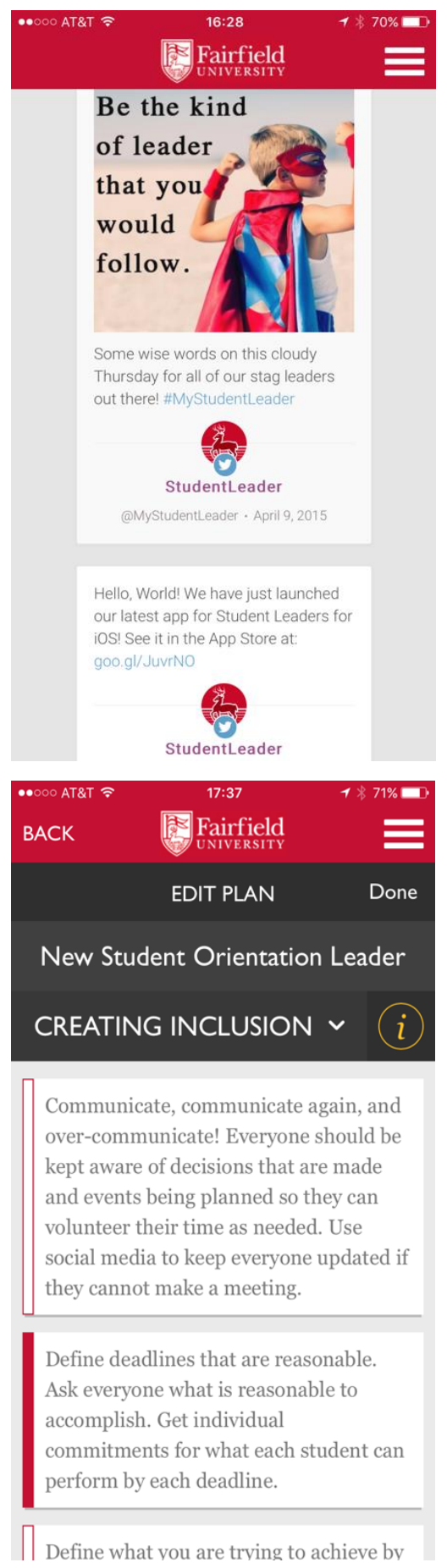

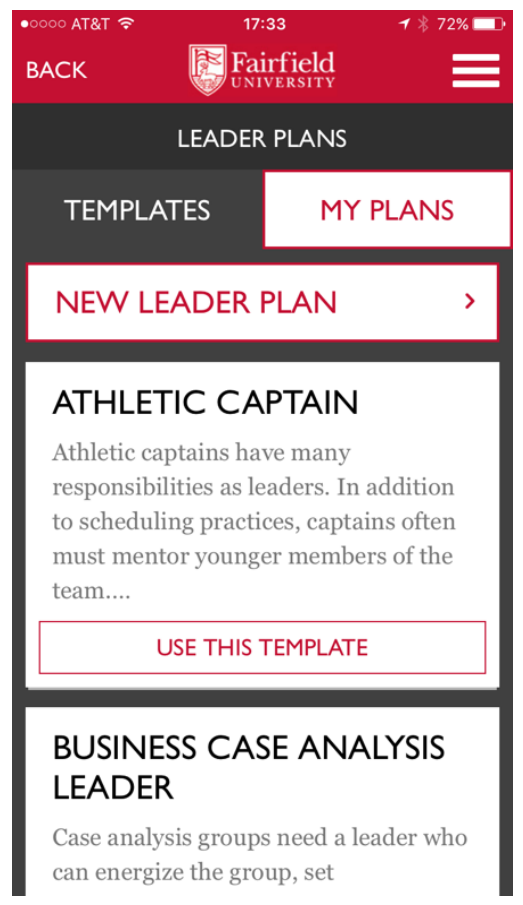
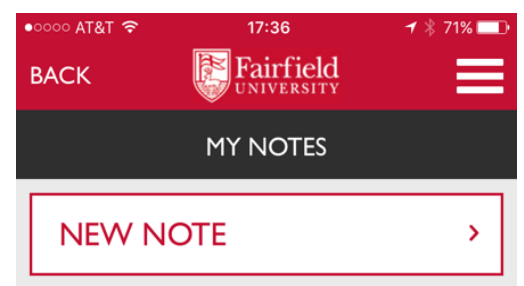

\section{ORDER PIZZA FOR 册 MEETING ON FRIDAY}

Two large pizzas. Pepperoni, onions, spinach, sausage. Deliver to Campus Center at 8 PM Friday

\begin{tabular}{|l|l|}
\hline EDIT & DELETE \\
\hline
\end{tabular}

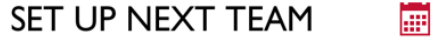
MEETING

Every Wednesday at 7:00 pm

\begin{tabular}{|l|l|}
\hline EDIT & DELETE \\
\hline
\end{tabular}

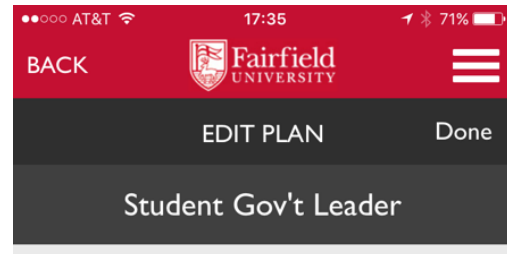

Select the first topic you want to start from, then move between topics to create your Leader Plan.

\section{CREATING INCLUSION}

FOSTERING TEAM COLLABORATION

HANDLING LOGISTICS AND PLANNING EVENTS

MAINTAINING ENGAGEMENT

\section{\begin{tabular}{lcc|}
$* \cdots 00$ AT\&T $₹=$ & $18: 49$ & $1 \% 78 \%$ \\
\hline PERSONAL LEADERSHIP & $\mathbf{X}$
\end{tabular}}

Leaving a leadership legacy involves having a lasting impact on others through your leadership skills.

I. What are the top ten leadership lessons you have learned from leading this student activity? Write them here.

2. Reflect on what you have learned as a leader. If you share your Leader Plan of selected tips, your wisdom and advice will live on.

3. Be certain to give credit to all who participated. Remember, student leadership is not about you; it is about the team.

Figure 1:

My Student Leader App Screen Shots 
Over the course of ten semesters, the effectiveness of co-curricular project assignments in Mg 240 has been greatly enhanced by the technology associated with the app. Students participated in campus activities, fundraising projects, club efforts, as well as service learning initiatives, allowing the app to be used in a robust way across campus. Over 155 Leader Plans have been filed to date, each unique, addressing specific leadership initiatives.

Reactions to the My Student Leader app. Students report the app helped them move beyond course content and connect class themes with their co-curricular campus leadership activities. Over the course of ten semesters, students were asked about how they used the and whether or not they found it useful to their learning. Here are five representative commentaries $(N=155)$ :

- In class, the material often goes by rather quickly. This app identifies what was specifically useful for me as I serve as a peer mentor. I loved the handling stress tips and time management tips.

- As captain of the rugby team, there are a lot of organizational and administrative duties I have to complete. This plan allowed me to think about everything I need to do and remind me of ways to develop my leadership skills. And I could put it all in the Notes to Self-section - very useful.

- This semester, I am in an entrepreneurship class in which we always talk about how entrepreneurs are apt to recognize a need, and that is what you have done with this app! When I think about all of the leadership groups, organizations, and committees that I have been a part of, this app would've come in so handy.

- I used the app for my service learning project with the YMCA Women's Group. As I scrolled through it, I learned a lot. Then I identified tips that I thought would be useful and pertinent to my project. I found over 40 tips I could use, and the process taught me a lot about leadership, planning, and the how-to's.

- [The app] drove home several points about leadership I had not considered when I read the material, allowed us to really think in advance about what we were doing for our project, and how I wanted to be as a leader, and helped me to understand how the concepts really apply to real-life.

Intersection of the My Student Leader App with Service Learning. Fifteen students $(N=15)$ who participated in service learning projects were asked to reflect on their experiences during Spring 2015. Two meaningful essay commentaries appear below:

Sample Essay \#1: Midnight Run. "We created a Leader Plan for Midnight Run that included excellent tips for how we wanted to lead our event. We used tips like "Plan the schedule of the event. Think about all the logical steps - what happens first, second, third? What can go wrong? What is essential to success?", and "Hold a kickoff meeting in which students identify what tasks need to be accomplished and by when". We were very focused on handling logistics, creating engagement, and managing stress. I listed over 38 Notes to Self on my phone about fundraising, getting to Manhattan, and figuring out what to bring and what to tell everyone.

When we arrived in Manhattan, we met the director of the program who drove with us in the vans to show us all the stops. From there, beautiful things 
happened. The director, who was homeless himself at one point in time, knew the spots where homeless people gather like the back of his hand. He directed us to each stop. Once we arrived at each stop, our chaperones, and the director stepped back. We met and greeted homeless people. We offered them sandwiches, clothing, toiletries, anything we had. There was an elderly woman who was freezing. She was begging for a jacket. I pulled out a purple jacket and her face lit up. She put it on and tears came to her eyes.

Afterwards, I wrote a Leadership Legacy entry about the experience. I learned a lot of things about myself as a leader through doing this project. I like to think that I am a good leader and treat others as human beings before "followers" when leading. The experience changed my outlook on life and has made me a more responsible citizen. I'm not a big "save the world" type, but this was meaningful for me and helped me to realize that becoming a strong leader is something I want to be."

Sample Essay \#2: Animal Welfare Bake Sale. "When I helped organize the animal welfare bake sale, I was in charge of maintaining contact with all my group members as well as organizing all the logistics. I used the Leader Plan function of the app for our Animal Welfare Bake Sale to think about how I wanted to lead this project. I searched the app for each theme. Under Creating Inclusion, I wanted to make sure everyone felt welcomed. So, I included, "Hold an initial welcome meeting so students each have an opportunity to contribute ideas and provide input to accomplish tasks". That was a really good leadership tip, because if I had not read that one, I probably would have just gone ahead and told them what to do myself. Because I allowed them to brainstorm, we ended up with better ideas.

I established the location downtown and found the table we could use for our event. Others in the group created posters and signs for our collection drive. Of our eight members, two could not go downtown at the time of our fundraising event. That actually worked out, as they participated in other aspects of the project, like baking. The day of the event we were super organized. I used Notes to Self to remind me of all the things we needed to bring to the location cupcakes, signs, posters, the table, a university flag, and all the rest. The event went off without a hitch. In this case, the amount of money raised, was our success scale. We raised enough money so that all the individuals involved in the project were very happy with the outcome.

At the start of the class I had the thought of, "Sure I can lead, I can just tell people what to do and how to do it and I will be considered a leader." I could not have been more wrong. I truly understand that to be a leader, it takes compassion as well and understanding. Understanding that sometimes your plan will not always work out the way in which you envisioned it. Being able to react and adjust can be a deciding factor that allows a leader to be successful or one that fails. Because I was able to lead in a real-world event, I showed myself that I 
could really be the leader I always wanted to be. The app was very helpful in setting the course for my leadership on this project and developing notes for what needed to be done."

\section{Practitioner Reflections}

There is a lot of work that goes into developing an app. My Student Leader represents a pedagogical initiative born from dogged determination, creativity, and the inspiration of digital native students. The value of the app is that it can bridge the gap between theory and practice. Treating a class as an active leadership laboratory with a variety of field projects that are taking place on different timelines on campus is not easy. This requires a strong level of confidence and professionalism on the part of instructors, who, instead of becoming a "sage on the stage", learn to be a "guide on the side" (King, 1993). Again, and again, students report the value of active learning as one of the main features of their college experiences.

My Student Leader encourages the development of a Leader Plan in advance of taking on a campus co-curricular project. This has turned out to be exceedingly helpful, as undergraduate students have wonderful and expansive leadership visions concerning what they want to accomplish, but poor management and execution skills. Filing a Leader Plan prior to committing to campus leadership allows students to consider their leadership approach before they jump into the project. There also was value to the shared email function as I was able to check on their plans and additional administrators and student peers could read them. The Notes to Self section was useful as it reminded students of important project deadlines.

The opportunity for reflection on leadership practice was informative. As listed in the commentaries presented in this article, students can reflect on what they learned and the connection between theory and practice. In addition, students can craft a Leadership Legacy statement, following the prompt, to reflect on leadership lessons learned. The app remains as long as they carry their smart phones; their Leadership Legacy commentaries go with them, even once class is completed.

\section{Recommendations (for Other App Creators)}

There are significant limitations in the use of this technology. Not all students will have smartphones, and many will not have access to the Apple App Store. We are considering removing the app from the App Store and developing an open access website, so all students can benefit. Most significantly, the app has executed two versions, Version 1.0 and Version 2.0, which coincided with Apple technology upgrades as well as Facebook's elimination of Parse and new iOS operating systems. However, technology redevelopment is expensive and will need to be revamped every time a technological or operating system change is announced. For that reason, given that the professor can only keep this going on a fixed budget, the app will need to be sunset from Apple's App Store in a few years. In the future, My Student Leader will continue to exist and be accessible via mobile technology through a browser hosted at the app's website at https://studentdigitalleadership.com. While leadership education spans decades, technology does not last forever. 
Finally, service learning is not without limitations (Butin, 2006). For this reason, faculty members often hesitate before allowing students to run amok with various service learning projects which they cannot directly supervise, provide oversight for, or control in the classroom. My Student Leader offers a nascent process by which to bridge technology to plan such projects while teaching the value of leadership. Nonetheless, students will still fail on certain projects, run into issues of inequitable commitments from peers, misappropriate resources, forget to check with administrative officials, and languish until the final deadline. My Student Leader asks students to reflect on their experiences as a means of closure, however - and experience shows that failed projects are often as instructive as successful ones.

In conclusion, My Student Leader represents a novel approach to the teaching of leadership for Millennials who expect digitally savvy solutions and information at their fingertips. It is hoped that this app will provide a window into the future so that educators consider how they can bridge the gap between mobile technologies and pedagogy to capture the attention of Millennial and Generation $\mathrm{Z}$ audiences.

\section{References}

Bauermeister, M., Greer, J., Kalinovich, A., Marrone, J., Pahl, M., Rocholz, L., \& Wilson, B. (2015). Preparing students for leadership through experiential learning. Journal of Leadership Education, 15(3). doi: 1012806/V15/I3/A4.

Butin, D. (2006). The limits of service learning in higher education. The Review of Higher Education, 29(4), 473-498. doi: 10.1353/rhe.2006.0025.

DeBlois, P. \& Oblinger, D. (2007). Learning technologies that serve students. In G.L. Kramer \& J.N. Gardner (Eds.). Fostering student success in the campus community (pp 145-170). San Francisco, CA: Jossey-Bass.

Eyler, J., Giles, G., Stentson, C. \& Gray, C. (2001). At a glance: What we know about the effects of service learning on college students, faculty, institutions and communities, 1993-2000 (3rd ed.). Nashville, TN: Vanderbilt University.

Fletcher, J. \& Kaufer, K. (2003). Shared leadership: Paradox and possibility. In C.L. Pearce, \& J.A. Conger, J. A. (2002). Shared leadership: Reframing the how's and why's of leadership (pp. 21-47). Thousand Oaks, CA: Sage Publications.

Friedel, C., Kirland, K. \& Grimes, M. (2014). Principles of peer leadership: An undergraduate course for students in positions to serve fellow students. Journal of Leadership Education, 15(2), 38-47. doi: 1012806/V15/12/A2.

Greenleaf, R. (1977). Servant leadership: A journey into nature of legitimate power and greatness. Mahwah, NJ: Paulist Press. 
Guthrie, K.L. (2009). Situated technology as student tool for leadership instruction. Journal of Leadership Education, 8(1), 130-136. doi.org/10.12806/v8/i1/ab3.

Hastings, L., Wall, M., \& Mantoya, K. (2018). Developing leadership through "serviceship": Leveraging the intersection between service learning and internships. Journal of Leadership Education, 17(1). doi: 10.12806/V17/I1/A2.

Kalinovich, A. \& Marone, J. (2017). Shared leadership: A primer and teaching recommendations for educators. Journal of Leadership Education, 16(1), 205-215 doi: 1012806/V16/I1/I1.

Kenworthy, A. \& Fornaicari, C. (2010). No more inventing the service learning wheel: Presenting a diverse compilation of best practice how to articles. Journal of Management Education, 34(1), 62-87. doi: 10:1177/1052562909346000.

King, A. (1993). From sage on the stage to guide on the side. College Teaching, 41(1), 30-35. doi.org/10.1080/87567555.1993.9926781.

Kolb, D. (1984). Experiential learning: Experience as the source of learning and development. Englewood Cliffs, NJ: Prentice Hall.

Kuh, G., Kinzie,J., Schuh,J., \& Whitt, E. (2005). Assessing conditions to enhance educational effectiveness: The inventory for student engagement and success. New York: John Wiley \& Sons.

Lantz-Andersson, A., Vigmo,S., \& Bowen, R. (2013). Crossing boundaries in Facebook: Students framing of language learning activities as extended spaces. International Journal of Computer Supported Collaborative Learning, 8(3), 293-312. doi.org/10.1007/s11412-013-9177-0.

McKim, A., \& Velez, J. (2017). Informing leadership education by connecting curricular experiences and leadership outcomes. Journal of Leadership Education, 16(1), 81-95. doi: 1012806/V16/I1/R6.

Mitchell, T. (2008). Traditional versus critical service learning: Engaging the literature to differentiate two models. Michigan Journal of Community Service Learning, 14(2), 5065. doi.org/10.3998/mjcsloa.3239521.0023.112.

Montiel, L., Delgado-Ceballos, J., \& Ortiz-de-Mandojana, N. (2017). Mobile apps for sustainability management education: The example of GoodGuide. Academy of Management Learning and Education, 16(3), 489-493. doi: AMLE - 2017-0184-BRR.

Odom, S., Jarvis, H., Sandlin, M., \& Peek, C. (2013). Social media tools in the leadership classroom: Students' perceptions of use. Journal of Leadership Education, 12(1), 34-53. doi.org/10.12806/v12/i1/34. 
O'Toole, J., Galbraith, J., \& Lawler, E. (2003). The promise and pitfalls of shared leadership. In C.L. Pearce, \& J.A. Conger, (Eds.). Shared leadership: Reframing the hows and whys of leadership (pp. 250-267). Thousand Oaks, CA: Sage Publications.

Outcalt, C., Faris, S., McMahon, K. (2001). Developing non-hierarchical leadership on campus: Case studies and best practices in higher education. Westport, CT: Greenwood Publishing.

Pearce, C. \& Conger, J. (2002). Shared leadership: Reframing the hows and whys of leadership. Thousand Oaks, CA: Sage Publications.

Pearce, C. \& Sims, H. (2000). Shared leadership: Toward a multilevel theory of leadership. Advances in the Interdisciplinary Studies of Work Teams, 7, 115-139. Greenwich, CT: JAI Press.

Stover, S. \& Seemiller, C. (2017). Moving students to deeper learning in leadership. Journal of Leadership Education, 16(4), 40-59. doi: 1012806/V16/I4/R3.

van Dierendock, D. (2011). Servant leadership: A review and synthesis. Journal of Management, 37(4), 1228-1261. doi/abs/10.1177/0149206310380462.

Vega, G. (2007). Teaching business ethics through service learning meta projects. Journal of Management Education, 31(5), 647-678. doi/abs/10.1177/1052562906296573.

Werner, L. Hellstrom, D., Chung, J., Kessinich, K., Taylor, L., \& Capeder, A. (2016). Bridging theory and practice in the leadership classroom: Intentional emergence as a modern pedagogy. Journal of Leadership Education, 15(4), 206-216. doi: 1012806/V15/I4/C1.

Whitaker, J., New, J. \& Ireland, R. (2015) MOOCs and the online delivery of business education: What's new? What's not? What now? Academy of Management Learning and Education, 15(2). doi: 10.5465/amle.2013.0021.

Yorio, P. \& Ye, F. (2012). A meta-analysis on the effects of service learning on the social, personal, and cognitive outcomes of learning. Academy of Management Learning and Education, 11(1), 9-27. doi: 10.5465/amle.2010.0072

\section{Author Biographies}

Lisa A. Mainiero, Ph.D is a Full Professor of Management and Leadership at the Dolan School of Business, Fairfield University, in Fairfield, Connecticut. She received her doctorate in Organizational Behavior from Yale University in 1983. Dr. Mainiero has published in journals such as the Academy of Management Review, the Journal of Career Development, and the Journal of Management. She is the Content Creator of the app. Contact: 1mainiero@ fairfield.edu. 
David M. Mangini, M.B.A., M.S., is a global strategist and founder of Mangini Strategic Advisors, L. L.C. He received his M.B.A. from the University of Connecticut, his M.S. in Electrical Engineering from Rensselear Polytechnic Institute, and his B.S. in Electrical Engineering from Worcester Polytechnic Institute. Along with Dr. Mainiero, he is the Technical Creator and co-founder of Soundview Horizons Digital Leadership, L.L.C. Contact: mangini.david@gmail.com.

Note: My Student Leader can currently be accessed through Apple's App Store. It will soon also be available at the app's website: https://studentdigitalleadership.com. 